\title{
DINAMIKA KOMUNIKASI ORGANISASI MASYARAKAT MARJINAL \\ (Studi Pada Komunitas Perempuan Pekerja Seks Yogyakarta)
}

\author{
Erwin Rasyid ${ }^{1}$ \\ ${ }^{1}$ Magister Penyuluhan dan Komunikasi Pembangunan \\ Sekolah Pascasarjana, Universitas Gadjah Mada Yogyakarta \\ Email: erwin.rasyid94@gmail.com
}

\begin{abstract}
Prostitution is sexual service for gaining cash. For someone who works in sexual service named as a prostitute or in Bahasa called as Pekerja Seks Komersial (PSK). Nowaday PSK term constructed by people to discriminate the sex labor. Sometimes Perempuan pekerja seks (PPS) obtain the negative streotype from society, because they know as a moral offender in social culture. The term commercial sex worker or "PSK" in Indonesia is one example of a form of community discrimination born of discourse formed by the mass media to women who work as a sex worker. In Special Region of Yogyakarta (DIY) there are some areas that are often the place where sex workers peddle. Namely Pasar Kembang area or better known as sarkem, the Tugu railway station (Ngebong) and in the Giwangans Terminal. In the three areas there are three communities that become a forum for organizing PPS, among others Bunga Seroja community in Sarkem, Arum Dalu Sehat community in Ngebong and Surti Berdaya community in Giwangan. The three communities are under the umbrella of an organization called Perhimpunan Perempuan Pekerja Seks Yogyakarta (P3SY) in Indonesia. This paper aims to analyze what kind of development communication system that attempted to be constructed by female sex workers in Yogyakarta. The method used is descriptive qualitative.
\end{abstract}

Keywords: Dynamics, Organization Communication and Female Sex Worker

\section{ABSTRAK}

Pelacuran atau prostitusi adalah penjualan jasa seksual atau hubungan seks untuk uang. Seseorang yang menjual jasa seksual disebut pelacur, yang kini disebut dengan istilah pekerja seks komersial atau PSK. Istilah PSK adalah bentuk diskriminasi masyarakat terhadap para pekerja seks. Dalam pengertian yang luas, sesorang yang menjual jasanya untuk hal yang dianggap tak berharga juga disebut melacurkan dirinya sendiri. Perempuan pekerja seks (PPS) sering mengundang streotipe negatif di berbagai lapisan masyarakat, karena dianggap pelaku pembelokan moral dan budaya yang ada di masyarakat. Istilah pekerja seks komersil atau "PSK" di Indonesia adalah salah satu contoh bentuk diskriminasi masyarakat yang lahir dari wacana yang dibentuk oleh media massa kepada perempuan yang bekerja sebagai pekerja seks. Di Daerah Istimewa Yogyakarta (DIY) ada beberapa daerah yang sering menjadi tempat para pekerja seks menjajakan. Yaitu kawasan Pasar Kembang atau lebih dikenal dengan sarkem, stasiun kereta api Tugu (Ngebong) dan Terminal Giwangans. Di tiga wilayah tersebut terdapat tiga komunitas yang menjadi wadah penyelenggaraan PPS, antara lain komunitas Bunga Seroja di Sarkem, komunitas Arum Dalu Sehat di Ngebong dan komunitas Surti Berdaya di Giwangan. Ketiga komunitas tersebut berada di bawah payung sebuah organisasi bernama Perhimpunan Perempuan Pekerja Seks Yogyakarta (P3SY) di Indonesia. Makalah ini bertujuan untuk menganalisis dinamika komunikasi organisasi pada komunitas pekerja seks perempuan yang ada di Yogyakarta. Metode yang digunakan adalah deskriptif kualitatif.

Kata Kunci: Dinamika Komunikasi Organisasi dan Perempuan Pekerja Seks 


\section{PENDAHULUAN}

Kaum marjinal sering dianggap sebagai bentukkegagalandaripembangunankhususnya dalam bidang investasi human capital. Selain itu, indikator pembangunan yang selalu menitik beratkan pada pembangunan sektor ekonomi dan politik membuat posisi kaum marjinal dalam struktur pembangunan semakin terjepit. Tak terkecuali bagi perempuan yang berprofesi sebagai pekerja seks atau sering disebut dengan pelacur.

Pelacuran atau prostitusi adalah penjualan jasa seksual atau hubungan seks untuk uang. Seseorang yang menjual jasa seksual disebut pelacur, yang kini juga disebut dengan istilah pekerja seks komersial atau PSK. Istilah PSK adalah bentuk diskriminasi masyarakat terhadap para pekerja seks. Dalam pengertian yang luas, sesorang yang menjual jasanya untuk hal yang dianggap tak berharga juga disebut melacurkan dirinya sendiri. Di Indonesia pelaku pelacuran sering disebut sebagai sundal. Ini menunjukan bahwa perilaku perempuan pekerja seks sangat begitu hina dan menjadi musuh masyarakat.

Pekerjaan melacur sudah dikenal di masyarakat sejak berabad lampau, ini terbukti dengan banyaknya catatan seputar mereka dari masa kemasa. Sejarah telah menuturkan banyak riwayat tentang perilaku seks manusia, mulai dari zaman pra-sejarah kini dengan ditemukannya berbagai ilustrasi yang secara antropologis dapat dikatakan sebagai riwayat tetang perilaku seks manusia (Sudarto, 2013). Resiko yang disebabkan akibat pelacuran antara lain adalah keresahan masyarakat dan dianggap sebagai biang penyebaran penyakit menular seksual, seperti HIV/ AIDS, Spilis dan sebagainya.

Perempuan pekerja seks (PPS) sering mengundang streotip negatif di berbagai lapisan masyarakat, karena dianggap pelaku pembelokan moral dan budaya yang ada di masyarakat. Stigma tersebut muncul sebagai akibat dari adanya norma perkawinan yang menjadi ideologi dominan di masyarakat. Dalam pandangan budaya patriaki PPS juga dianggap sebagai bentuk kemiskinan struktural. Hal ini timbul dari adanya pembagian kelas dalam budaya patriaki yang menempatkan kaum perempuan berada di bawah dominasi kaum laki-laki.

Para pekerja seks sering kali mengalami kekerasan psikis maupun fisik dari para pelanggan. Perlakuan kasar dan diskriminasi yang terima oleh para pekerja seks acap kali tidak terselesaikan dengan baik. Muara hukum yang tak jelas serta kurangnya kepeduliaan masyarakat terhadap para pekerja seks juga turut mempengaruhi hal tersebut.

Meskipun demikian, beberapa diantara PPS tersebut berupaya untuk keluar dari profesinya. Sikap itu telah menunjukan bahwa para PPS memiliki niat positif untuk berubah, namun paradigma yang telah melekat di masyarakat membuat para PPS kesulitan untuk keluar dari keadaanya sekarang karena minimnya peran pemerintah dalam mengentaskan fenomena tersebut. Oleh sebab itulah kemudian beberapa pekerja seks yang ada di Yogyakarta membentuk komunitas yang tersebar di masing-masing wilayah 
sebagi bentuk gerakan perlawanan terhadap diskriminasi yang mereka terima.

Di Daerah Istimewa Yogyakarta terdapat beberapa kawasan yang sering menjadi tempat para pekerja seks menjajakan diri. Di antaranya adalah kawasan Pasar Kembang atau yang lebih dikenal sarkem serta di kawasan terminal giwangan. Kawasan Pasar Kembang (Sarkem) ini terletak di gang-gang sempit di belakang gedung pemerintahan menuju Stasiun Tugu. Biasanya para PPS lokal yang berada disini berasal dari daerah Parangkusumo, Parangtritis dan Bantul. Kebanyakan PPS juga berasal dari luar Yogyakarta, ada yang berasal dari Temanggung, Semarang, Kudus, Pati, Purwodadi, Rembang, Kendal, Nganjuk, bahkan Jawa Timur dan Kalimantan.

Sementara itu di kawasan Giwangan terdapat sekitar 200 pekerja seks dengan umur rata-rata 25-50 tahun yang setiap malamnya menyebar di kawasan jalan lingkar utara dan selatan sekitar terminal (https://nasional. tempo.co/read/news/2012/12/19/058449079/ memotret-angkringan-dan-pekerja-seksgiwangan0). Angkringan menjadi semacam etalase bagi para pekerja seks. Ada pengunjung yang sekedar mampir, ada pula yng menawar hingga terjadi kesepakatan harga. Transaksi terjadi di angkringan, pelanggan mulai dari anak SMP, mahasiswa, hingga orang-orang tua. Kemudian wilayah lain yang juga sering disinggahi oleh beberapa PPS adalah Bong Suwung atau Ngebong. Daerah ini terletak di sepanjang pinggiran rel kereta api stasiun Tugu Yogyakarta. PPS yang mendiami tempat tersebut biasanya berasal dari eks PPS yang dulunya sering mangkal di Sarkem.
Para PPS di Sarkem membentuk komunitas "Bunga Seroja", di Ngebong mereka menyebut komunitasnya sebagai "Arum Dalu Sehat" atau ADS, kemudian di Giwangan menamakan komunitasnya dengan sebutan "Surti Berdaya". Ketiga komunitas tersebut selanjutnya membentuk satu payung organisasi bersama yang diberi nama Perhimpunan Perempuan Pekerja Seks Yogyakarta (P3SY). Organisasi inilah yang kemudian menjadi alat advokasi bagi mereka seperti untuk memperoleh akses layanan kesehatan, perlindungan hukum, dan sebagainya.

Manifestasi gerakan perempuan dalam wujud komunitas yang dilakukan oleh para PPS di Yogyakarta menunjukkan bahwa terdapat kesadaran untuk berorganisasi di kalangan kaum marjinal. Kesadaran kolektif tersebut tumbuh dari adanya kesamaan nasib yang dialami oleh para anggota dari komunitas tersebut. Sehingga mereka kemudian menciptakan sebuah ruang ekspresi yang digunakan untuk mencapai tujuan bersama dengan cara yang formal dan terstruktur dengan rapi.

Karena selama ini pandangan dan persepktif masyarakat terhadap pekerja seks lebih banyak dipengaruhi oleh konstruksi media massa. Konstruksi realitas yang dihadirkan oleh media massa lebih didominasi oleh adanya penekanan kesan negatif terhadap pekerja seks. Penekanan tersebut kemudian menimbulkan stigma negatif dan diskirminasi masyarakat terhadap perempuan yang berprofesi sebagai pekerja seks. Konstruksi inilah yang kemudian berusaha dilawan oleh komunitas pekerja seks melalui penciptaan media alternatif berupa buku. 
Bentuk penyampaian realitas tersebut disampaikan dalam buku yang yang berjudul "Dari Sarkem, Di Balik Stasiun Hingga Di Antara Debu Terminal: Mozaik Kisah Perempuan Perkasa". Para PPS melakukan gerakan dengan mengembangkan wacana perlawanan melalui tulisan yang menyingkap tabir kehidupan mereka. Buku tersebut merupakan media alternatif hasil dari gerakan civil society yang ada di Yogyakarta.

Apa yang dilakukan oleh komunitas PPS di atas merupakan satu bentuk dari penciptaan sistem komunikasi pembangunan untuk melawan wacana dominan terhadap kelompok mereka. Gerakan advokasi melalui jalur organisasi dianggap lebih efektif ketimbang hanya bergerak sendiri-sendiri. Bergerak secara berkelompok menjadi pilihan yang ditempuh oleh pekerja seks yang ada di Yogyakarta untuk memperjuangkan hakhak mereka sebagai warga negara. Menurut Johnson \& Johnson (2012) kelompok dapat diartikan sebagai sejumlah orang yang berkumpul bersama untuk mencapai suatu tujuan. Kelompok itu ada untuk suatu alasan dan orang membentuk kelompok untuk mencapai tujuan yang tidak dapat mereka capai sendiri.

Dalam suatu kelompok, terdapat suatu struktur dan pembagian peran dari masingmasing anggota yang berhimpun di dalamnya. Struktur tersebut dapat berbentuk formal maupun non-formal. Para pekerja seks yang ada di Yogyakarta dalam hal ini membentuk suatu kelompok dengan susunan struktur organisasi yang berbentuk formal. Struktur organisasi P3SY terdiri dari ketua, wakil ketua, sekretaris, bendahara dan anggota. Kemudian pada tataran komunitas, masing-masing wilayah juga memiliki struktur organisasi yang hampir sama dengan P3SY. Untuk lebih jelasnya, berikut ini adalah susunan organisasi P3SY yang menaungi tiga komunitas dari masing-masing wilayah:

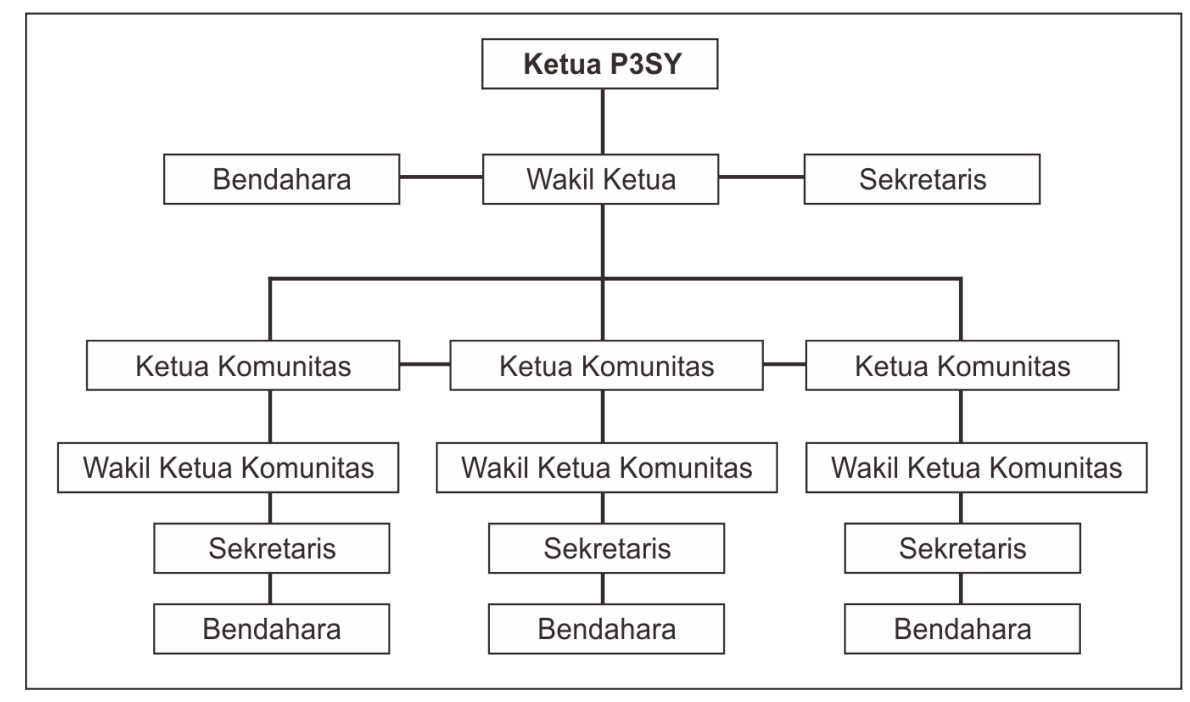

Gambar 1.

Struktur Organisasi P3SY 
Struktur organisasi di atas menunjukkan adanya dua bentuk struktur formal yang terdapat di P3SY. Yaitu struktur formal pada tingkatan organisasi P3SY dan struktur formal yang terdapat pada tataran komunitas yang berada di bawah naungan P3SY. Keberadaan dua bentuk struktur tersebut kemudian akan membentuk jalur kordinasi dan komunikasi yang berbeda pula pada masing-masing tingkatan struktural organisasi. Pola-pola komunikasi berperan penting dalam memajukan studi mengenai organisasi yaitu dengan menunjukkan pentingnya pola-pola komunikasi dalam pembangunan hubungan jaringan, struktur kekuasaan dan budaya (Morissan, 2013).

Seperti yang telah dijelaskan sebelumnya bahwa P3SY merupakan organisasi yang terdiri dari tiga komunitas yang berbeda dan berasal dari wilayah yang berbeda pula. Artinya, terdapat tiga kelompok yang mewakili suara masing-masing wilayah tempat mereka berasal. Hal ini kemudian akan menimbulkan dinamika kelompok yang berpengaruh terhadap proses komunikasi organisasi P3SY.

Masing-masing komunitas yang terdapat didalamP3SY akan memiliki pengaruh terhadap kebijakan dan keputusan organisasi. Selain itu, letak geografis dari tiga wilayah prostitusi yang berbeda tentu membuat dinamika kelompok dalam proses komunikasi dalam organisasi P3SY menjadi semakin menarik.

Paper ini kemudian berusaha untuk menjelaskan mengenai bagaimana dinamika dalam komunikasi organisasi di kalangan masyarakat marjinal khusus pada komunitas PPS yang ada di Yogyakarta.

\section{METODE PENELITIAN}

Pendekatan yang digunakan dalam paper ini adalah kualitatif dengan metode deskriptif. Penelitian ini dilakukan di tiga wilayah prostitusi yang ada di wilayah Yogyakarta, yaitu Sarkerm, Ngebong dan Giwangan. Sumber data berasal dari hasil pengamatan yang dilakukan oleh penulis selama satu tahun di tiga tempat lokalisasi yang ada di Yogyakarta. Yaitu kawasan Pasar Kembang (Sarkem), Ngebong dan Terminal Giwangan. .

Teknik pengumpulan data yang digunakan adalah deep interview (wawancara mendalam), observasi non partisipatif dan studi literatur dalam buku "Dari Sarkem, Di Balik Stasiun Hingga Di Antara Debu Terminal: Mozaik Kisah Perempuan Perkasa”.

Adapun unit yang dianalisis adalah pola komunikasi organisasi dari komunitaskomunitas yang berada di bawah naungan Perhimpunan Perempuan Pekerja Seks Yogyakarta (P3SY).

Validitas data yang terkumpul dari hasil wawancara dan observasi kemudian akan diuji dengan kombinasi teknik triangulasi metode dan triangulasi peneliti. Setelah menguji validitas, data tersebut selanjutnya dianalisis dengan teknik analisis data interaktif yang terdiri dari reduksi data, interpretasi data dan penarikan kesimpulan.

\section{HASIL DAN PEMBAHASAN}

Perbedaan gender melahirkan konstruksi sosial mengenai pembagian peran antara laki-laki dan perempuan. Yang kemudian 
mengakibatkan marginalisasi terhadap kaum perempuan baik dalam sistem budaya, sosial, politik hingga pembangunan. Hal inilah yang kemudian terjadi pada kalangan marjinal perempuan pekerja seks di Yogyakarta. Pembagian peran tersebut tidak hanya memarjinalkan mereka namun menjadikan mereka miskin secara struktural. Sehingga penindasan yang terjadi tidak hanya pada tataran ideologis semata, bahkan terjadi dalam segala aspek kehidupan.

Fakih (2013) mengungkapkan bahwa ketidakadlian gender tersebut telah mengakibatkan kaum perempuan menganggap bahwa kondisi dan ketidakadilan yang mereka terima sebagai sesautu yang normal dan kodrati. Apa yang diperjuangkan oleh para pekerja seks di Yogyakarta tidak hanya sekedar persoalan mengenai penindasan yang berasal dari kaum laki-laki, melainkan perlawanan terhadap sistem dan struktur pembangunan yang menghasilkan ketidakadilan gender bagi mereka. Lebih lanjut Fakih (2013) kemudian mengungkapkan bahwa gerakan transformasi gender lebih merupakan gerakan pembebasan perempuan dan laki-laki dari sistem yang tidak adil.

Rogers dan Adhikarya (Nasution, 2009) merumuskan beberapa prinsip dalam strategi komunikasi pembangunan, salah satunya adalah mengaktifkan keikutsertaan agen-agen perubahan yang berasal dari kalangan masyarakat sebagai petugas lembaga pembangunan yang beropreasi di kalangan sejawat mereka sendiri. Prinsip inilah yang kemudian diterapkan oleh P3SY dalam sistem komunikasi pembangunan yang mereka kembangkan. Yaitu dengan dengan meningkatkan partisipasi para PPS sebagai sesama kaum marjinal untuk menyuarakan apa yang mereka harapkan.

Gerakan perempuan dalam kerangka feminisme pada dasarnya tidak memiliki tujuan untuk membalas penindasan yang mereka alami dari kaum laki-laki. Namun lebih kepada mentransformasikan suatu hubungan antar sesama manusia baik dari segi budaya, ekonomi, politik maupun hubungan dengan kaum laki-laki. Dalam konteks kaum marjinal, apa yang dilakukan oleh komunitas perempuan pekerja di Yogyakarta merupakan bentuk perlawanan terhadap wacana paradigma developmentalism. Paradigma ini mengasumsikan bahwa perempuan tidak berpartisipasi dalam pembangunan sehingga mengakibatkan mereka menjadi terbelakang. Mansour Fakih (2013) menungkapkan bahwa:

"Melawan hegemoni yang merendahkan perempuan adalah dengan cara melakukan dekonstruksi ideologi. Melakukan dekonstruksi artinya mempertanyakan kembali segala sesuatu yang menyangkut nasib perempuan di mana saja, pada tingkat dan dalam bentuk apa saja. Pertanyaan tersebut dapat dimulai dari kasus yang sifatnya makro seperti Women in Development (WID) sampai kasus-kasus yang dianggap kecil yakni pembagian peran gender di rumah tangga."

Asusmsi di atas menunjukkan bahwa wacana perlawanan kaum perempuan terhadap hegemoni kaum laki-laki dalam sturktur pembangunan terjadi pada skala makro dan mikro. Hegemoni menurut Gramsci 
(Sugiono, 2006) adalah bentuk supremasi satu kelompok atau beberapa kelompok atas yang lainnya dengan bentuk supremasi lain yang dinamakan "dominiasi", yaitu kekuasaan yang ditopang oleh kekuatan fisik. Menyusun sistem komunikasi pembangunan untuk mendekonstruksi ideologi dan peran perempuan dalam pembangunan merupakan bentuk manifestasi gerakan perlawanan kaum perempuan terhadap hegemoni dan penindasan yang mereka alami.

Dekonstruksi ideologi yang berusaha dihadirkan oleh komunitas PPS di Yogyakarta adalah dengan menerbitkan suatu media alternatif untuk melawan wacana dominan yang dibentuk oleh kuasa media dan hegemoni kaum laki-laki. Media alternatif tersebut dihadirkan melalui pengembangan wacana komunikasi pembangunan dalam sebuah buku yang memuat tulisan dari anggota-anggota komunitas.

Laclau dan Mouffe (Jorgensen dan Phillips, 2010) mengembangkan teori dekonstruksi sebagai metode untuk mengungkap kandungan ideologis teori-teori yang lain melalui kontradiksi-kontradiksi yang diidentifikasi dan ditransformasikan ke dalam piranti-piranti untuk direnungkan lebih lanjut. Teori ini berasal dari penggabungan dan modifikasi dua tradisi teoritis utama yaitu marxisme dan strukturalisme.

Selain melalui media alternateif seperti buku, kaum PPS di Yogyakarta juga mengembangkan media komunitas sebagai upaya dalam mendukung pergerakan mereka. Yaitu dengan membentuk organisasi P3SY sebagai cara untuk menghadirkan relasi dan struktur sosial di antara para perempuan yang berprofesi sebagai pekerja seks.

\section{Wacana Komunikasi Komunitas PPS}

Sebagai bagian dari golong masyarakat termarjinalkan, kesadaran pekerja seks di Yogyakarta untuk membentuk suatu organisasi adalah bagian dari pembentukan sistem komunikasi pembangunan untuk memperjuangkan hak mereka. Kerangka wacana tekstual yang dihadirkan oleh P3SY dalam bukunya merupakan bentuk penyampaian komunikasi kepada masyarakat yang berada di luar kelasnya. Khususnya bagi pemerintah dan masyarakat yang menjadikan mereka sebagai golongan yang termarjinalkan.

Jika menyusun secara konsep, maka posisi kaum marjinal khususnya komunitas PPS dalam struktur masyarakat adalah sebagai berikut:

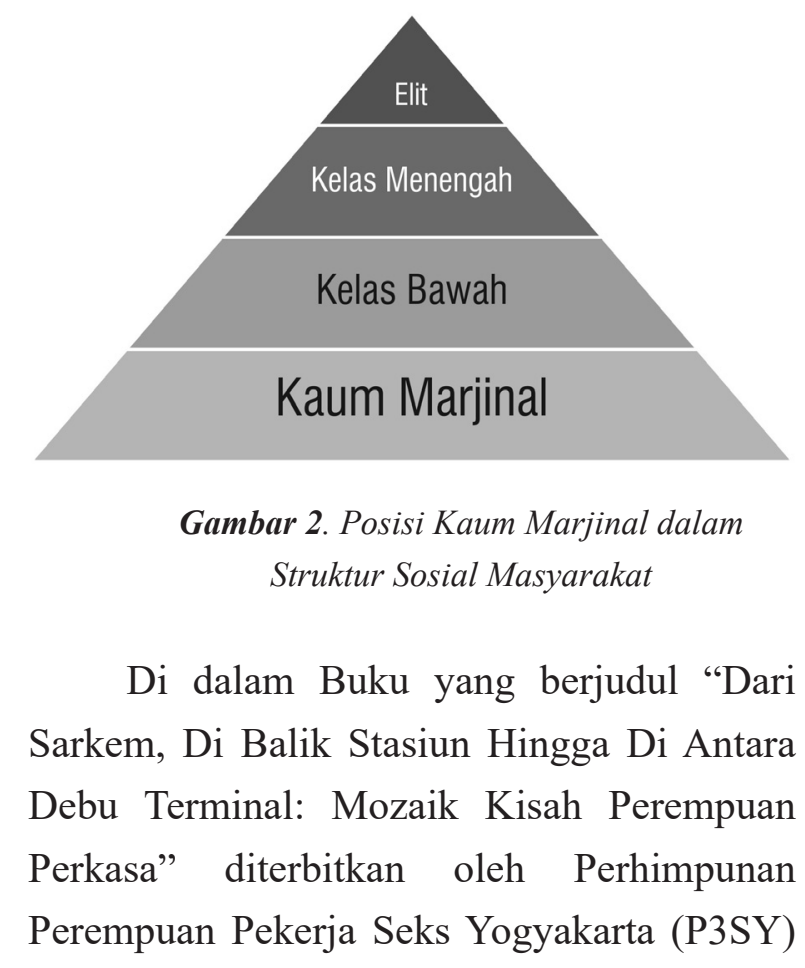


pada tahun 2014. Terdapat beberapa tulisan yang menjelaskan mengenai manifestasi P3SY sebagai gerakan kaum perempuan dalam membela hak kaum marjinal dalam struktur pembangunan.

Buku P3SY di awali dengan tulisan dari ketua P3SY yang bernama Sarmi. Di dalam tulisannya yang berjudul "Kisah Perjalanan Hidup Kartini Pasar Kembang", Sarmi membahas mengenai kisah perjalanan hidupnya menjadi seorang pekerja seks dan ketua dari organisasi yang memperjuangkan hak-hak kaum perempuan khususnya yang berprofesi sebagai pekerja seks.

Sarmi juga mengungkapkan bahwa hal yang melatarbelakanginya untuk memperjuangkan teman-temannya sesama pekerja seks adalah karena kesamaan nasib yang dialaminya. Yaitu menjadi korban dari seorang laki-laki yang tidak bertanggung jawab. Selain itu, alasan lain yang dia ungkapkan dalam tulisannya adalah:

"Satu hal lagi yang membuat aku ingin memperjuangkan teman-teman pekerja seks karena waktu itu layanan bagi pekerja seks belum ada yang mengorganisir. Teman-teman pekerja seks banyak yang kebingungan dalam pemeriksaan kesehatan. Akhirnya waktu itu aku bekerja sama dengan mbak Dewi untuk mengorganisir pelayanan kesehatan bagi pekerja seks. Saat itulah aku sadar bahwa teman-teman pekerja seks membutuhkan pendampingan dan arahan."

Apa yang diungkapkan oleh Sarmi di atas mengisyaratkan bahwa kaum marjinal khususnya perempuan pekerja seks masih kebingungan dalam mengakses programprogram pembangunan seperti misalnya pelayanan kesehatan. Sarmi kemudian mengambil tindakan untuk mengorganisir dan melakukan pendampingan terhadap para pekerja seks. Hal tersebut merupakan satu wacana komunikasi pembangunan yang secara tidak sadar dikembangkan oleh Sarmi untuk membantu temantemannya.

Sarmi tidak hanya sekedar memposisikan dirinya sebagai pekerja seks, namun sebagai ketua P3SY dia juga berperan dalam membentuk dialektika dikalangan pekerja seks untuk mempertanyakan seperti apa posisi mereka dalam program pembangunan. Sarmi menyadari bahwa pekerja seks merupakan bagian dari kaum kelas yang termarjinal.

Kemudian pada tulisan disampaikan oleh AN (inisial) dalam tulisannya yang berjudul "Karena Ini adalah Panggilan Hati" pada halaman sembilan, dia menyampaikan bahwa alasan dia ikut aktif dalam P3SY adalah karena panggilan hati untuk ikut membantu dan memperjuangkan nasib temantemannya. Alasan lain yang AN utarakan hampir sama dengan Sarmi, dorongan untuk ikut memperjuangkan nasib pekerja seks di Yogyakarta adalah karena persamaan nasib yang mereka alami.

Sementara di tulisan lainnya yang disampaikan oleh NA (inisial) yang berjudul "Realita Hidup Perempuan Tangguh dari Bong Suwong" pada halaman 28-33, dia menyampaikan beberapa hal yang menjadi tuntutannya, yaitu:

a. Kami sama seperti rakyat yang lain 
jadi samakan hak kami sebagai rakyat Indonesia.

b. Jangan anggap pekerjaan kami sebagai pekerjaan yang hina, karena ini semua bukan pilihan hidup tapi hanya perjalanan hidup saat ini.

c. Berikan hak kesehatan kami yang layak.

d. Berikan pembekalan untuk para karyawan rumah sakit dengan detail tentang ODHA dan penyakit HIV dan AIDS serta penyakit menular seksual. Karena terkadang ODHA dan pekerja seks terlalu dianggap menjijikkan.

e. Berikan kami perlindungan karena kami banya didiskriminasi oleh banyak kalangan

Beberapa poin yang disampaikan oleh NA lebih kepada tuntutan kepada Pemerintah khususnya adalah untuk lebih memperhatikan nasib para pekerja seks. HIV dan AIDS merupakan wacana yang selalu berkembang seiring dengan kehadiran pekerja seks yang dianggap sebagai pihak yang paling bertanggung jawab dalam menularkan penyakit seksual. Sehingga apa yang diungkapkan oleh NA juga hampir sama dengan wacana yang dikembangkan oleh Sarmi mengenai akses pelayanan dan pendampingan kesehatan bagi para pekerja seks.

Perhatian utama yang disampaikan P3SY dalam bukunya adalah terkait dengan masalah kesehatan. Sebagai kaum yang dianggap sebagai pihak yang paling bertanggung jawab dalam menularkan penyakit seksual, P3SY berusaha untuk melawan opini tersebut dengan tuntutan peningkatan pelayanan kesehatan terhadap mereka. Selain akses layanan kesehatan, tuntutan lain yang disampaikan oleh para pekerja seks dalam bukunya adalah mengenai penyediaan lapangan pekerjaan. Seperti yang diungkapan oleh TM (inisial) pada halaman 80 berikut ini:

"Bagi masyarakat yang membacana buku ini, siapapun anda dan dimana anda berada, aku berharap anda bisa membuka lapangan pekerjaan bagi kami para PPS, agar PPS bisa berkurang. Misal dengan membuka warung usaha, memberi modal dan sebagainya."

Tidak hanya TM, Ikajuga menyampaikan harapannya terkait dengan tulisan yang dia buat dan ditujukan kepada pemerintah dan masyarakat:

"Harapanku setelah sekolah jurnalistik ini, aku berharap masyarakat dapat melihat dan membaca karya kami. Sehingga mereka sadar bahwa perempuan pekerja seks juga bisa berkarya. Aku juga berharap pemerintah dapat lebih perhatian dengan nasib aku dan teman-temanku yang lain."

Beberapa pendapat yang disampaikan oleh masing-masing PPS dalam tulisannya juga semakin dipertegas oleh Sarmi bahwa sudah sepatutnya para pekerja seks dapat mengadvokasi diri mereka, karena hal tersebut sudah menjadi hak mereka sebagai warga negara. Sarmi mengungkapkan bahwa keberadaan P3SY sebagai organisasi yang menaungi tiga komunitas yang ada di Sarkem, Ngebong dan Giwangan adalah untuk mempersatukan ketiga komunitas tersebut. Ber- 
gerak bersama dalam memperjuangkan hakhak mereka serta menghapus diskriminasi dan stigma masyarakat dan pemerintah terhadap PPS. Organisasi inilah yang kemudian menjadi medium komunikasi kaum marjinal khususnya komunitas PPS di Yogyakarta dalam memperlihatkan partisipasi, ide dan gagasan pembangunan yang mereka wacanakan.

\section{Model Komunikasi Organisasi Komunitas PPS}

P3SY pada dasarnya merupakan organisasi perempuan yang memiliki tujuan untuk mendampingi dan mengadvokasi perempuan pekerja seks yang ada di Yogyakarta. Manifestasi gerakan adalah menimbulkan kesadaran para anggotanya melaluikomunikasi organisasibaik dalamranah komunitas maupun P3SY sebagai organisasi yang menghimpun komunitas tersebut. Sifat terpenting komunikasi organisasi adalah penciptaan pesan, penafsiran, dan penanganan kegiatan anggota organisasi (Ishak, 2012). Namun dalam prosesnya, ada beberapa hal yang turut mempengaruhi proses penyampaian pesan dalam komunikasi organisasi P3SY.

Proses komunikasi organisasi yang terjadi pada komunitas pekerja seks yang terhimpun dalam Perhimpunan Perempuan Pekerja Seks Yogyakarta (P3SY) tidak terlepas dari tekanan-tekanan kelompok yang ada di dalamnya. Setiap komunitas memiliki tujuan dan kepentingan masing-masing. Hal ini kemudian akan menimbulkan adanya perbedaan pendapat di antara komunitaskomunitas tersebut dan turut mempengaruhi setiap pengambilan keputusan organisasi. Sehingga mengakibatkan terjadinya polarisasi dalam internal P3SY.

Hasil penelitian di lapangan menunjukkan bahwa kondisi geografis menjadi salah satu faktor utama yang mempengaruhi kualitas komunikasi organisasi yang dihasilkan oleh P3SY. Di antaranya adalah sulitnya mengadakan rapat rutin organisasi mulai dari penentuan lokasi rapat hingga kendala alur kordinasi antar komunitas. Letak geografis dan lokasi yang berbeda dari masing-masing komunitas mempengaruhi proses penyampaian pesan dalam komunikasi organisasi P3SY.

Salah satu hambatan terbesar bagi kelancaran arus komunikasi adalah keadaan atau sikap yang sudah melekat, membudaya dalam orga-nisasi itu sendiri, terdapat jarak fisik antar orang, dan tempat yang berjauhan, karena waktu yang dibutuhkan dalam system komunikasi organisasi memerlukan waktu cukup panjang, berliku-liku, lambat dan lama sekali prosesnya (Rahmanto, 2004).

Sebagai ketua organisasi, Sarmi adalah sosok yang selalu menjadi rujukan dalam setiap pengambilan keputusan organisasi di P3SY. Tidak hanya di P3SY, di komunitas-komunitas seperti Bunga Seroja, Surti Berdaya dan ADS juga menjadikan ketua masing-masing sebagai rujukan utama dalam setiap keputusan yang dihasilkan. Maka jika merujuk pada teori jaringan komunikasi, bentuk komunikasi ini merupakan jaringan komunikasi yang berbentuk roda yaitu menjadikan pemimpin sebagai fokus perhatian setiap anggota kelompok. 


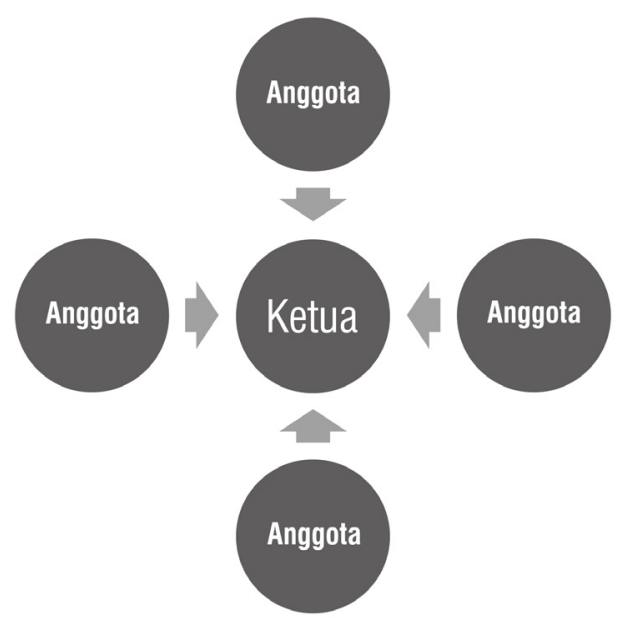

Gambar 3. Jaringan Komunikasi P3SY

Ada beberapa hal mengakibatkan mengapa anggota dari masing-masing komunitas maupun P3SY hanya bergantung pada pemimpin mereka. Yang pertama adalah belum adanya kohesifitas pada tiga komunitas yang terhimpun dalam P3SY. Hanya sebagian anggota yang bersedia untuk menyuarakan dan menyampaikan aspirasinya. Anggota-anggota inilah yang kemudian biasanya menduduki posisi struktural di dalam komunitas maupun P3SY. Seperti Sarmi yang menjabat sebagai ketua P3SY dan komunitas Bunga Seroja, kemudian MT (inisial) sebagai ketua komunitas Surti Berdaya dan AN (inisial) sebagai ketua ADS.

Sementara tipe kepemimpinan yang terdapat di P3SY adalah kepemimpinan demokratis yaitu mendorong setiap anggota untuk memutuskan setiap kebijakan organisasi. Tipe ini dipilih karena tingkat partisipasi anggota dalam komunitas maupun P3SY dianggap masih rendah dan hanya bergantung pada ketua. Sehingga diperlukan adanya suatu dorongan agar semua anggota dapat terlibat aktif dalam setiap kegiatan organisasi.
Menurut Gibb (dalam Rakhmat, 2014) kepemimpinan demokratis paling efektif bila (1) tidak ada anggota kelompok yang merasa dirinya lebih mampu mengatasi persoalan dari kelompok yang lain (2) bila metode komunikasi yang tepat belum diketahi atau tidak dipahami dan (3) bila semua anggota kelompok berusaha mempertahankan hak-hak individual mereka.

Peranan masing-masing anggota maupun komunitas dalam P3SY terdiri dari beberapa bentuk. Pertama adalah Energizer yaitu sebagai pihak yang mendorong kelompok untuk bertindak atau mengambil keputusan. Peran ini biasanya di ambil alih oleh masingmasing ketua komunitas di P3SY. Kemudian Opinion Giver sebagai pihak yang memberikan pendapat atau saran alternatif bagi kelompok. Peran ini biasanya diberikan kepada sosok yang dianggap senior di masing-masing komunitas. Selain sebagai opinion giver, mereka juga berperan sebagai Orienter atau pengarah. Dan yang terakhir adalah Follower yaitu anggota yang ikut bergabung dan mengikuti kegiatan kelompok namun berperan pasif dalam setiap pengambilan keputusan organisasi.

Faktor situasional yang terdapat pada masing-masing komunitas juga memiliki pengaruh dalam proses komunikasi organisasi P3SY. Terdapat perbedaan jumlah pekerja seks dari masing-masing wilayah prostitusi di Yogyakarta. Hal ini kemudian mengakibatkan adanya perbedaan jumlah anggota pada masing-masing komunitas antara Bunga Seroja, Surti Berdaya dan ADS.

Dari segi komunikasi, makin besar 
kelompok, makin besar kemungkinan sebagian besar anggota tidak mendapat kesempatan berpartisipasi (Rakhmat, 2014). Masalah inilah yang kemudian terjadi pada komunitas Bunga Seroja di Sarkem. Sebagai pusat lokalisasi di Yogyakarta, maka jumlah pekerja seks yang terdapat di lokasi tersebut juga sangat besar. Sehingga hal tersebut mengakibatkan rendahnya partisipasi anggota di Bunga Seroja.

Berbeda dengan Surti Berdaya di Giwangan dan ADS di Ngebong, jumlah pekerja seks yang ada di sana jauh lebih sedikit dibandingkan dengan yang ada di Sarkem. Sehingga tingkat partisipasi anggota di kedua komunitas tersebut juga cukup tinggi. Hal tersebut dapat terlihat dari banyaknya jumlah anggota yang hadir dalam setiap agenda pertemuan rutin (perut) yang diadakan oleh Surti Berdaya dan ADS.

Perbedaan ukuran kelompok antara Bunga Seroja dengan Surti Berdaya dan ADS tidak hanya berpengaruh terhadap tingkat partisipasi anggota pada masingmasing komunitas. Namun terdapat pula perbedaan dalam efektifitas yang juga turut mempengaruhi setiap pengambilan keputusan dari ketiga komunitas tersebut. Proses komunikasi yang terdapat pada komunitas Surti Berdaya cenderung monoton karena kurangnya masukan dan gagasan dari anggota. Sementara di komunitas Surti Berdaya dan ADS cenderung memiliki dinamis.

Masing-masing pekerja seks yang menjadi anggota komunitas di Sarkem, Giwangan dan Ngebong memiliki karakter yang berbeda-beda. Pekerja seks yang ada di Sarkem biasanya merupakan pendatang baru dan cenderung inklusif ketika baru pertama kali datang di sana. Mereka masih memiliki kecemasan dan perlu menyesuaikan diri dengan kondisi yang mereka hadapi. Hal ini kemudian juga berpengaruh terhadap komunitas Bunga Seroja yang kesulitan untuk merangkul anggota tersebut.

Sementara pekerja seks yang terdapat di Giwangan dan Ngebong adalah mereka yang sudah lama tinggal dan menetap di wilayah tersebut. Selain itu, beberapa dari mereka juga adalah pekerja seks yang pindah dari wilayah Sarkem. Sehingga karakter pekerja seks yang terdapat kedua wilayah ini cenderung eksklusif dan mudah berbaur dengan anggota komunitas yang lain. Hal ini pula yang mendorong tingginya tingkat partisipasi anggota di komunitas Surti Berdaya dan ADS.

Alasan dibalik rendahnya tingkat partisipasi anggota di P3SYbisa dilihat dari berbagai aspek. Salah satunya dengan meninjau ulang keputusan anggota tersebut bergabung dalam kelompok. Jika melihat dari apa yang terjadi pada P3SY, keputusan tersebut dipengaruhi oleh adanya faktor kebutuhan interpersonal yaitu untuk mengakses layanan kesehatan, sosial dan sebagainya. Beberapa anggota dari komunitas masih memprioritaskan pekerjaannya sebagai pekerja seks dan hanya menjadikan organisasi P3SY sebagai fasilitas sosial untuk memenuhi kebutuhan mereka.

Masing-masing komunitas di sarkem, giwangan dan ngebong memiliki tujuan yang berbeda-beda. Tujuan yang ingin dicapai 
kelompok dapat berupa perubahan sikap, perilaku, kemampuan, produktivitas, dsb (Maryani 1997). Begitu pula dengan ketiga komunitas yang bernaung di P3SY. Keputusan anggota untuk bergabung di Bunga Seroja, Surti Berdaya dan ADS dipengaruhi oleh lingkungan tempat mereka berada. Motif pekerja seks di Sarkem untuk bergabung di Bunga Seroja lebih didominasi oleh alasan karena keinginan untuk mendapatkan fasilitas yang diakses jika tergabung ke dalam komunitas.

Sementara alasan pekerja seks di Giwangan dan Ngebong untuk bergabung di komunitasnya masing-masing lebih bervariasi. Yang pertama karena adanya keinginan untuk meningkatkan kapasitas diri, mengakses layanan kesehatan dan adanya rasa solidaritas antar sesama anggota yang berprofesi sebagai pekerja seks. Hal ini pula yang melandasi adanya perbedaan karakteristik di antara ketiga komunitas tersebut dan turut mempengarui proses komunikasi organisasi P3SY.

Komunikasi organisasi adalah interaksi dan interdependensi yang terdiri dari komunikator, pesan, media, komunikan, dan dampak komunikasi dalam mencapai tujuan organisasi melalui pembagian pekerjaan dan fungsi hirarki otoritas dan tanggung jawab (Farihanto, 2010). Sedangkan proses komunikasi organisasi di P3SY, interaksi yang terjadi hanya antar sesama hirerarki yang memiliki tanggung jawab dalam struktural organisasi. Seperti yang telah dijelaskan sebelumnya bahwa kondisi letak geografis yang berbedabeda di antara tiga komunitas di P3SY tidak memungkinkan untuk adanya partisipasi aktif dari anggota.
Proses komunikasi organisasi yang penting adalah bagaimana membuat makna dari suatu informasi sama di antara pemberi informasi dan penerima informasi (Kuswarno, 2001). Efektifitas komunikasi organisasi P3SY akan dipengaruhi oleh bagaimana proses penyampaian aspirasi dari masing-masing komunitas dapat tersampaikan dengan baik oleh ketua komunitas yang menjadi struktural P3SY. Kuswarno (2001) juga mengungkapkan bahwa selain proses pemaknaan pesan yang akan menentukan perilaku hubungan komunikator dan komunikate di dalam organisasi, jumlah pesan akan menentukan juga perilaku orang yang terlibat dalam proses komunikasi organisasi tersebut.

Proses penyampaian pesan yang tidak efektif tentu saja bisa menimbulkan konflik di antara sesama anggota dan komunitas di P3SY. Karena komunikasi dapat merupakan suatu sumber konflik (Ibrahim, 1979). Oleh karena itu tekanan kelompok dalam proses komunikasi organisasi P3SY tidak hanya berpengaruh terhadap partisipasi anggota dan komunitas di dalamnya. Namun hal tersebut dapat pula mengakibatkan timbulnya kesalahapahaman yang berujung pada terjadinya konflik. Sehingga P3SY perlu meminimalisir adanya potensi kegagalan komunikasi dalam setiap proses komunikasi organisasi yang terjadi baik itu di antara sesama anggotanya maupun dengan sesama komunitas.

\section{PENUTUP}

Perempuan pada dasarnya juga memiliki peran penting dalam penyelanggaraan pemba- 
ngunan. Namun ketidakadilan gender yang mengakibatkan timbulnya streotipe kemudian mengakibatkan posisi kaum perempuan menjadi terpinggirkan dalam struktur pembangunan. Sehingga kaum perempuan perlu untuk melawan paradigma tersebut dengan sistem komunikasi pembangunan yang mampu menghasilkan keadilan gender di dalamnya.

Ada banyak hal yang mempengaruhi proses komunikasi organisasi yang terjadi di P3SY. Faktor situasional dan personal merupakan faktor dominan yang berpengaruh terhadap proses komunikasi organisasi P3SY. Karakteristik masing-masing komunitas juga turut menentukan bagaimana partisipasi pekerja seks yang tergabung di dalamnya. Letak geografis yang cukup jauh di antara ketiga komunitas tersebut menjadi alasan utama terhambtanya proses interkasi yang terjalin di antara sesama anggota dan komunitas.

P3SY perlu membuat sistem komunikasi organisasi yang efektif agar proses penyampaian pesan dan pengambilan keputusan organisasi dapat berjalan dengan lancar. P3SY dapat membuat pembagian peran bagi anggota dan komunitasnya agar alur kordinasi di dalam struktural P3SY dapat berfungsi dengan baik. Sehingga tujuan dari P3SY sebagai manifestasi gerakan perempuan dapat terwujud.

\section{DAFTAR PUSTAKA:}

Fakih, Mansour. (2013). Analisis Gender \& Transformasi Sosial. Yogyakarta: Pustaka Pelajar

Fakih, Mansour. (2013). Runtuhnya Teori Pembangunan dan Globalisasi. Yogyakarta: Pustaka Pelajar

Farihanto, Muhammad Najih.(2010). "Komunikasi Organisasi Dalam Penanaman Budaya Organisasi Di Seminari Tinggi Santo Paulus Yogyakarta." : 179-94.

Ibrahim, Syafei. (1979). "Komunikasi Sebagai Faktor Determinan Dalam Organisasi. ”: 291-301.

Ishak, Aswad. 2012. Peran Public Relation dalam Komunikasi Organisasi. Jurnal Komunikasi, Volume 1, Nomor 4, Januari 2012. Hlm. 373-380

Kuswarno, Engkus. (2001). "Efektivitas Komunikasi Organisasi." Mediator 2(1): 5561. repository.usu.ac.id/bit-stream/ 123456789/47147/4/Chapter II.pdf.

Maryani, Anne. (1997). "Komunikasi Persuasif, Kohesi Kelompok, Dan Apresiasi Seni Gamelan Sunda: Kasus Di Kalangan Mahasiswa Anne."

Johnson, David dan Frank P. Johnson. (2012). Dinamika Kelompok: Teori dan Keterampilan. Jakarta: Indeks

Jorgensen W. Marianne dan Louise J. Phillips. (2010). Analisis Wacana: Teori dan Metode. Yogyakarta: Pustaka Pelajar

Nasution, Zulkarimen. (2009). Komunikasi Pembangunan: Pengenalan Teori dan Penerapannya. Jakarta: Rajawali Pres

Perhimpunan Perempuan Pekerja Seks Yogyakarta. (2014). Dari Sarkem, Di Balik Stasiun Hingga Di Antara Debu Terminal: 
Mozaik Kisah Perempuan Perkasa. Yogyakarta: PKBI

Rahmanto, Aris Febri. (2004). Peranan Komunikasi Dalam Organisasi. Jurnal Komunikologi Volume 1 Nomor 2. Hlm. 59-75.

Rakhmat, Jalaluddin. (2015). Psikologi Komunikasi. Bandung: Remaja Rosdakarya

Sudarto.(2013). SilaturahmiKelamin:Menyingkap Tabu-Tabu Dunia Perkelaminan. Yogyakarta: Pintal

Sugiono, Muhadi. (2006). Kritik Antonio Gramsci Terhadap Pembangunan Dunia Ketiga. Yogyakarta: Pustaka Pelajar 